\title{
Molecular Determinants of Cardiac Arrhythmias
}

\author{
Diego Franco \\ Cardiovascular Development Group, Department of Experimental Biology, University of Jaén, 23071 Jaen, Spain; \\ dfranco@ujaen.es
}

Received: 26 October 2020; Accepted: 28 October 2020; Published: 30 October 2020

check for updates

Cardiac arrhythmias are defined as electrical disorders of the pumping heart, including therein a wide range of physiopathological entities. Cardiac arrhythmias can be secondary to existing structural pathologies such as cardiac hypertrophy, dilated cardiomyopathy and/or valvular heart diseases, or they can be primary in origin, i.e., without previously existing structural defects. According to the cardiac chambers that are primarily affected, electrical disorders can be defined as ventricular or supraventricular. Ventricular arrhythmias comprise the most severely affecting diseases, including herein ventricular fibrillation, catecholaminergic polymorphic ventricular taquicardia (CPVT), short-QT, long-QT and Brugada syndromes, respectively. The prevalence of these arrhythmias is low, with estimates of 1:2000/1:5000 in long QT syndrome [1] and Brugada syndrome [2] while in other ventricular arrhythmias, such as CPVT and short-QT syndrome, no conclusive data have been reported to date [2-5], but the burden of the impact is enormous since in many cases it results in sudden death. A particular case also affecting the ventricular chambers is arrhythmogenic right ventricular dysplasia (ARVD) in which both structural and electrical remodeling concomitantly co-exist. Importantly, ARVD is also frequently associated with sudden death. Within the supraventricular arrhythmias, the most frequent type is atrial fibrillation, with an estimate incidence of $2-3 \%$ in the general population but rising to all $10 \%$ in the elderly. The natural course of AF is, in many cases, relatively benign, but the incidence of additional complications such as stroke is substantially high [6].

Over the last decade, our current understanding of the genetic determinants of cardiac arrhythmias has enormously increased. Catecholaminergic polymorphic ventricular taquicardia (CPVT) have been linked to six distinct loci, of which only two correspond to ion channels. Short-QT syndrome has been associated to at least three loci, all of them coding for potassium channels. Long-QT syndrome has been associated to 16 distinct loci [7], most of them linked to ion channels with a functional impact of the regulation of the cardiac action potential, including on the sodium, calcium and potassium ion channels, yet in some cases, the functional implication of the associated genes remains to be determined [8]. Brugada syndrome is also linked to nine distinct loci, all but one involving ion channels $[9,10]$. The genetics of ARVD is more complex, to date associated to 14 distinct loci, among which most of them correspond to cell-cell contact proteins, while one ion channel is reported and three distinct loci remain to be linked to a specific gene [11-15]. On the other hand, the genetics of ventricular fibrillation remains largely enigmatic with only one gene linked to this cardiac arrhythmia. In line with the findings of ventricular arrhythmias, the genetics of supraventricular arrhythmias, i.e., atrial fibrillation, has also been extensively studied. Currently, 18 distinct loci are linked to familial atrial fibrillation, most of them associated to ion channel mutations, while an increasing number of them have been linked to distinct genetic variants in different chromosomal localizations by using genome-wide association studies [16-18].

Surprisingly, although a large number of genetic loci have been linked to several of these cardiac arrhythmias, they only explain a relatively small subset of cases, demonstrating that novel molecular substrates are still be discovered. For example, culprit candidate genes only explained approximately $30-35 \%$ of Brugada syndrome cases [9,19] and $20-25 \%$ of familial atrial fibrillation [16-18]. 
Furthermore, although our current understanding of the genetic and molecular determinants of cardiac arrhythmias has greatly enlarged in recent decades, a large number of gaps remain to be resolved. Mutations in multiple genes have been linked to cardiac arrhythmias, but the mode of action, in many cases, is scarcely deciphered. Pioneered works were performed in heterologous cell systems but limitations soon arise and thus novel tissue and organ-based models were required to fully understand their physiopathological contribution. The advent of CRISP-CAS9 gene editing is considered to be a highly promising tool to speed on deciphering such roles. In addition, the impairment of complex multiprotein regulatory mechanisms and subcellular trafficking pathways of distinct ion channels can also contribute to cardiac arrhythmias thus opening new fields of research.

GWAS have greatly broadened our current understanding of the genetic substrates leading to cardiac arrhythmias, however, many of the risk variants identified are located in intergenic regions, hampering a direct and clear cause effect between the identified variants, the culprit gene and the electrophysiological underlying defects [20]. The successful identification of key regulatory elements affecting key ion channels and/or transcriptional regulatory factors have been reported [21-23] but to date they represent the exception to the rule. In recent years, the discovery of novel non-coding RNAs and their complex and intricate mechanisms of action in multiple biological settings have provided evidence that non-coding RNAs are differentially expressed in different cardiac arrhythmias. Thus, it is plausible that they will constitute new players involved in cardiac arrhythmias broadening thus the genetic and molecular substrates underlying these cardiac physiopathological conditions. In this Special Issue of Hearts, we aim to provide a scientific forum to increase our understanding of the molecular determinants of cardiac arrhythmias.

Funding: This work is supported by grants from the Ministry of Science, Innovation and Universities for the Spanish Government (BFU2015-67131P) and grants-in-aid from the Junta de Andalucía Regional Council (CTS-446).

Conflicts of Interest: The author declares no conflict of interest.

\section{References}

1. Bezzina, C.R.; Barc, J.; Mizusawa, Y.; Remme, C.A.; Gourraud, J.B.; Simonet, F.; Verkerk, A.O.; Schwartz, P.J.; Crotti, L.; Dagradi, F.; et al. Common variants at SCN5A-SCN10A and HEY2 are associated with Brugada syndrome, a rare disease with high risk of sudden cardiac death. Nat. Genet. 2013, 45, 1044-1049. [CrossRef]

2. Brugada, J.; Campuzano, O.; Arbelo, E.; Sarquella-Brugada, G.; Brugada, R. Present Status of Brugada Syndrome: JACC State-of-the-Art Review. J. Am. Coll. Cardiol. 2018, 72, 1046-1059. [CrossRef]

3. Brugada, R.; Campuzano, O.; Sarquella-Brugada, G.; Brugada, J.; Brugada, P. Brugada syndrome. Methodist Debakey Cardiovasc. J. 2014, 10, 25-28. [CrossRef] [PubMed]

4. Campbell, H.M.; Wehrens, X.H.T. Genetics of atrial fibrillation: An update. Curr. Opin. Cardiol. 2018, 33, 304-310. [CrossRef]

5. De Villiers, C.P.; van der Merwe, L.; Crotti, L.; Goosen, A.; George, A.L., Jr.; Schwartz, P.J.; Brink, P.A.; Moolman-Smook, J.C.; Corfield, V.A. AKAP9 is a genetic modifier of congenital long-QT syndrome type 1. Circ. Cardiovasc. Genet. 2014, 7, 599-606. [CrossRef] [PubMed]

6. Feghaly, J.; Zakka, P.; London, B.; MacRae, C.A.; Refaat, M.M. Genetics of Atrial Fibrillation. J. Am. Heart Assoc. 2018, 7, e009884. [CrossRef] [PubMed]

7. Gourraud, J.B.; Barc, J.; Thollet, A.; Le Marec, H.; Probst, V. Brugada syndrome: Diagnosis, risk stratification and management. Arch. Cardiovasc. Dis. 2017, 110, 188-195. [CrossRef]

8. Guerrier, K.; Kwiatkowski, D.; Czosek, R.J.; Spar, D.S.; Anderson, J.B.; Knilans, T.K. Short QT Interval Prevalence and Clinical Outcomes in a Pediatric Population. Circ. Arrhythmia Electrophysiol. 2015, 8, 1460-1464. [CrossRef]

9. Haissaguerre, M.; Vigmond, E.; Stuyvers, B.; Hocini, M.; Bernus, O. Ventricular arrhythmias and the His-Purkinje system. Nat. Rev. Cardiol. 2016, 13, 155-166. [CrossRef] [PubMed]

10. Hayashi, K.; Tada, H.; Yamagishi, M. The genetics of atrial fibrillation. Curr. Opin. Cardiol. 2017, 32, 10-16. [CrossRef]

11. Juang, J.J.; Horie, M. Genetics of Brugada syndrome. J. Arrhythmia 2016, 32, 418-425. [CrossRef] 
12. Kirsch, L.R.; Weinstock, D.J.; Magid, M.S.; Levin, A.R.; Gold, J.P. Treatment of presumed arrhythmogenic right ventricular dysplasia in an adolescent. Chest 1993, 104, 298-300. [CrossRef] [PubMed]

13. Man, J.C.K.; Mohan, R.A.; Boogaard, M.V.D.; Hilvering, C.R.E.; Jenkins, C.; Wakker, V.; Bianchi, V.; Laat, W.; Barnett, P.; Boukens, B.J.; et al. An enhancer cluster controls gene activity and topology of the SCN5A-SCN10A locus in vivo. Nat. Commun. 2019, 10, 4943. [CrossRef] [PubMed]

14. McKenna, W.J.; Thiene, G.; Nava, A.; Fontaliran, F.; Blomstrom-Lundqvist, C.; Fontaine, G.; Camerini, F. Diagnosis of arrhythmogenic right ventricular dysplasia/cardiomyopathy. Br. Heart J. 1994, 71, 215-218. [CrossRef]

15. Nakano, Y.; Shimizu, W. Genetics of long-QT syndrome. J. Hum. Genet. 2015, 61, 51-55. [CrossRef] [PubMed]

16. Nava, A.; Bauce, B.; Basso, C.; Muriago, M.; Rampazzo, A.; Villanova, C.; Daliento, L.; Buja, G.; Corrado, D.; Danieli, G.A.; et al. Clinical profile and long-term follow-up of 37 families with arrhythmogenic right ventricular cardiomyopathy. J. Am. Coll. Cardiol. 2000, 36, 2226-2233. [CrossRef]

17. Rampazzo, A.; Nava, A.; Miorin, M.; Fonderico, P.; Pope, B.; Tiso, N.; Livolsi, B.; Zimbello, R.; Thiene, G.; Danieli, G.A. ARVD4, a new locus for arrhythmogenic right ventricular cardiomyopathy, maps to chromosome 2 long arm. Genomics 1997, 45, 259-263. [CrossRef]

18. Schwartz, P.J.; Stramba-Badiale, M.; Crotti, L.; Pedrazzini, M.; Besana, A.; Bosi, G.; Gabbarini, F.; Goulene, K.; Insolia, R.; Mannarino, S.; et al. Prevalence of the congenital long-QT syndrome. Circulation 2009, 120, 1761-1767. [CrossRef]

19. Severini, G.M.; Krajinovic, M.; Pinamonti, B.; Sinagra, G.; Fioretti, P.; Brunazzi, M.C.; Falaschi, A.; Camerini, F.; Giacca, M.; Mestroni, L. A new locus for arrhythmogenic right ventricular dysplasia on the long arm of chromosome 14. Genomics 1996, 31, 193-200. [CrossRef]

20. Van den Boogaard, M.; Barnett, P.; Christoffels, V.M. From GWAS to function: Genetic variation in sodium channel gene enhancer influences electrical patterning. Trends Cardiovasc. Med. 2014, 24, 99-104. [CrossRef]

21. Van den Boogaard, M.; Wong, L.Y.; Tessadori, F.; Bakker, M.L.; Dreizehnter, L.K.; Wakker, V.; Bezzina, C.R.; 't Hoen, P.A.; Bakkers, J.; Barnett, P.; et al. Genetic variation in T-box binding element functionally affects SCN5A/SCN10A enhancer. J. Clin. Investig. 2012, 122, 2519-2530. [CrossRef]

22. Jame, S.; Barnes, G. Stroke and thromboembolism prevention in atrial fibrillation. Heart 2020, 106, 10-17. [CrossRef]

23. Vutthikraivit, W.; Rattanawong, P.; Putthapiban, P.; Sukhumthammarat, W.; Vathesatogkit, P.; Ngarmukos, T.; Thakkinstian, A. Worldwide Prevalence of Brugada Syndrome: A Systematic Review and Meta-Analysis. J. Am. Coll. Cardiol. 2017, 69, 523.

Publisher's Note: MDPI stays neutral with regard to jurisdictional claims in published maps and institutional affiliations.

(C) 2020 by the author. Licensee MDPI, Basel, Switzerland. This article is an open access article distributed under the terms and conditions of the Creative Commons Attribution (CC BY) license (http://creativecommons.org/licenses/by/4.0/). 